\title{
Mantle metasomatism and crustal contamination in carbonatites the East African Rift - A case study of Sukulu and Tororo (Uganda)
}

Z. BENKÓ ${ }^{1}$, T. MAGNA ${ }^{2}$, K. MOLNÁR ${ }^{1}$, V. RAPPRICH ${ }^{2}$, L. PALCSU $^{1}$, G. CZUPPON ${ }^{1,3}$, B. ČEJKOVÁ ${ }^{2}$

${ }^{1}$ Inst. Nuclear Physics, Debrecen, Hungary; benko.zsolt@atomki.mta.hu

${ }^{2}$ Czech Geological Survey, Prague, Czech Republic

${ }^{3}$ Inst. Geol. Geochem. Research, RCAES, Budapest, Hungary

The world-class apatite deposits of Sukulu and Tororo carbonatite complexes (SE Uganda; Paleogene to Neogene age) are magmatic-hydrothermal products of the East African rift system. Noble gas ( $\mathrm{He}, \mathrm{Ne}, \mathrm{Ar})$ and $\mathrm{H}$ isotope analysis, as well as microthermometry measurements on fluid inclusions hosted by calciocarbonatites, combined with bulk-sample $\delta^{18} \mathrm{O}, \delta^{13} \mathrm{C}$ analysis and trace element measurements, have been carried out to constrain the source regions, formation and post-emplacement processes, and evaluate economic potential of the strategic metals (e.g. REE, $\mathrm{Nb}$ ).

The primary two-phase aqueous liquid + vapour fluid inclusions in apatite display homogenization temperatures between $270-350^{\circ} \mathrm{C}$ and $250-300^{\circ} \mathrm{C}$ for the Sukulu and Tororo, respectively. The observed low temperatures and relatively high salinities $(13-18 \mathrm{NaCl}$ equiv. wt $\%)$ of the fluids imply that the carbonatites are hydrothermal (or strongly hydrothermally overprinted) in origin and can be classified in terms of their origin as carbohydrothermal.

The ${ }^{3} \mathrm{He} /{ }^{4} \mathrm{He}$ ratios ranging from 6.5 to $9.3 \mathrm{R}_{\mathrm{A}}, \mathrm{Ne}$ isotope ratios $\left({ }^{20} \mathrm{Ne} /{ }^{22} \mathrm{Ne}=9.4-11.8 ;{ }^{21} \mathrm{Ne} /{ }^{20} \mathrm{Ne}=0.028-0.041\right)$, as well as stable $\mathrm{C}-\mathrm{O}$ isotopes $\left(\delta^{18} \mathrm{O}=7.5-8.9 \%\right.$,,$\delta^{13} \mathrm{C}=-3.85$ to $-1.07 \%$ ) indicate that the carbonatites originated ultimately from a 'MORB-like' mantle source. Barium concentrations, $\mathrm{Nb} / \mathrm{Y}$ ratios as well as the total REE vs. $\mathrm{Sr} / \mathrm{Ba}$ inter-relations imply only a limited contamination of the primary mantle derived fertile magma with REE-enriched subcontinental mantle lithosphere.

The more radiogenic noble gas compositions, higher $\mathrm{Ba}$ and SREE concentrations, and lower homogenization temperatures of the Tororo complex imply extended crustal interaction for the fluids and/or contamination of the parent magma with a metasomatized subcontinental mantle lithosphere.

Supported by the Czech Science Foundation (19-29124X). 